\title{
Religion in the Roman Empire
}

\section{Volume 4}

No. 2

2018

\section{Religious Terminology}

Rubina Raja, Jörg Rüpke

Introduction: Coming to Terms with Ancient Religion

Maik Patzelt

The Rhetoric of Roman Prayer. A Proposal for a Lived Religion Approach

Celia E. Schultz

Sacrum Reddere: Sacrifice, Consecration, and Dedication in Roman Religion

\section{Jörg Rüpke}

Gifts, Votives, and Sacred Things. Strategies, Not Entities

\section{Rubina Raja}

The Matter of the Palmyrene 'modius'. Remarks on the History of Research into the Terminology of the Palmyrene Priestly Hat

Søren Lund Sørensen

Herod's Oath of c. 6 в 


\section{Religion in the Roman Empire}

Edited by Jan Dochhorn (Durham), Maren Niehoff (Jerusalem), Rubina Raja (Aarhus), Christoph Riedweg (Zürich), Jörg Rüpke (Erfurt), Christopher Smith (St Andrews), Moulie Vidas (Princeton), Markus Vinzent (London) and Annette Weissenrieder (Halle)

The Religion in the Roman Empire journal concentrates on original research and review articles. Submission of a paper will be held to imply that it contains original unpublished work that is not being submitted for publication elsewhere. All articles are refereed by specialists. Acceptance for publication will be given in writing. When an article is accepted for publication, the exclusive copyright is granted to Mohr Siebeck for publication in a print and an electronic version. Further information on this and the rights retained by the author can be found atwww.mohr.de/RRE. Please contact rights@mohrsiebeck.com.

Please send manuscripts and editorial inquiries to:

Prof. Dr. Jörg Rüpke

Universität Erfurt

Max-Weber-Kolleg für kultur- und sozialwissenschaftliche Studien

Postfach 900221

99105 Erfurt / Germany

E-mail:rre@uni-erfurt.de

\section{Full Text Online}

The subscription is valid for one location (single-site: one site = one city) of a medium-sized institution (up to 40,000 users). If your institution is larger than 40,000 users (FTE), or has several locations, please contact the publisher to receive an offer. Contact: brixner@mohrsiebeck.com

In order to set up online access for institutions/libraries, please go to: http://www.ingentaconnect.com/register/institutional.

In order to set up online access for private persons, please go to: http://www.ingentaconnect.com/register/personal.

Publisher: Mohr Siebeck GmbH \& Co. KG, Postfach 2040, 72010 Tübingen Can be purchased at bookstores.

(C) 2018 Mohr Siebeck Tübingen. www.mohrsiebeck.com

The journal and all the individual articles and illustrations contained in it are protected by copyright. Any utilization beyond the narrow confines of copyright law without the publisher's consent is punishable by law. This applies in particular to copying, translations, microfilming and storage and processing in electronic systems.

Typeset by Martin Fischer, Tübingen.

Printed by Gulde-Druck, Tübingen.

Printed in Germany. 


\section{Rubina Raja, Jörg Rüpke}

\section{Introduction: Coming to Terms with Ancient Religion}

Our approach to distant cultural phenomena, in general, and ancient religion, in particular, is shaped by the terminology we use - be it ancient terminology as handed down to us or terminology developed and used in a modern context. The very concept of 'religion' has been criticised and even avoided on these grounds. The same is true for 'gods' and 'heroes', and other terms of intermediate range, such as 'priests' and 'ritual', but 'cult' or 'mysteries', 'holy places' and 'the sacred', have also become a matter of debate and criticism in the past decades. Against the background of a 'Comparative Religion' that constituted its objects and their comparability by applying a set of such words as foundational terms, attempts have been made in the past decade to critically review the use of such terminology in lexica and handbooks. ${ }^{1}$ As part of the 'linguistic turn', concepts such as 'religion' have been characterised as 'essentially contested' 2 in a manner similar to the critical review of 'formative terms' in Sociology in more recent years. ${ }^{3}$

Within the disciplines of Archaeology and Ancient History, the shifts of focus and debates have not just made scholars more aware of the importance of terminology. Rather, they have also led to fruitful discussions about the use of terminology and also the lack of knowledge about the way in which terms were applied in Antiquity. Although terminology has sometimes also been applied incorrectly, in general a more critical awareness has grown from such debates, having implications that are both more profound and broader than their consequences for the use of terminology within the field of ancient religion. Working from the basis of 'hard' empirical evidence from archaeological (mostly objects and complexes) or historical sources (usually texts and inscriptions), scholars are often confronted with frustrating situations in which they are not able to decipher iconography and descriptions in texts as well as inscriptions on the basis of already known material.

\footnotetext{
1 Cancik et al. 1988-2001; Taylor 1998.

2 For the concept, see Gallie 1956, 195.

3 See, e.g., Knöbl 2007.
} 
They must, therefore, sometimes speculate or cast their interpretative nets very wide.

In Religious Studies, one of the consequences has been a shift to discursive studies, observing how such terms - and above all 'religion' - have historically been used. This has set it further apart from approaches and whole disciplines that focus on practices and material objects outside of, or even beyond, the available textual evidence. The terms mentioned above offer starting points for cross-cultural (Greek and Roman, Indian and Mediterranean) or cross-period comparison (republican and imperial, pagan and Christian). Scholarly interests are as much focussed on similarities as they are on differences, admittedly favouring the essentialisation of 'cultures' as bounded units of human practices. Archaeology of religion is a case in point, now trying to start from fields of practices and experiences rather than objects or supposedly fixed rituals. ${ }^{4}$

The same sensibility and differentiated evaluation has rarely been applied to terms on a lower level, terms that refer to undeniably existing material objects or elementary actions. Here, discussions have focussed on problems of intra-cultural lexica and 'Eigenterminologie'. If this is helpful for probing into the conceptual background of objects and practices, it also leads to the prioritising of legal or intellectual discourses, selected historiographic, or even antiquarian, discourses over the perspectives of local practitioners, artisans, or users. Even if the latter are frequently beyond recovery, they must at least be taken into account as agents who appropriate or even outright contradict such discourses. Practical consequences for our use of ancient terminology are manifest. Terms and definitions of terms need to be historicised, with regard to ancient use as well as modern (respectively early modern) re-invention. The ways in which they relate to specific phenomena cannot be taken for granted but need to be investigated; definitions and the claims of their authors, their auctores, need to be critically reviewed. This issue of the RRE offers critical reflections on, and attempts at the historicisation of, a number of key concepts in classical studies. It intends to spur further engagement with the importance of terminology within the field of ancient religion and all other disciplines, which deal with ancient religion. Only through a continuous engagement between the involved disciplines will it be possible to push such debates further. Therefore, the current issue does not offer a coherent or holistic take on terminology as such but is, rather, constituted by a set of articles, which deal with different ways of approaching terminology, be it tackling terminology as used in practice,

4 Raja and Rüpke 2015. 
the impact of terminology, or the historiography of terminology. In this issue, ancient historians, classical archaeologists and historians of religion are brought together in order to offer various perspectives, which all need to be taken into consideration when engaging with terminology. It becomes clear that there is no 'one size fits all' approach when tackling ancient terminology or the terminology applied to ancient objects by modern scholarship. Every researcher, so to say, needs to start over and engage with the terminology in context - both its original context as well as the discourse, which may have developed around it.

In this issue, Maik Patzelt begins by questioning the concept of prayer and the associations connected with it. He is able to show that the concept isolates and generalises just a few features of a much wider ancient art of 'rhetoric of the communication with the divine.' Such 'rhetorical' techniques include verbal and non-verbal elements that are referred to by a wide range of ancient terms. These terms and their interpretative value and admonitory character are investigated in their textual contexts. It is shown to what degree they convey situational normative statements as well as how they shift the foci of their interests. The bulk of the material is taken from the first century CE.

The focus moves from praying to consecrating in the article written by Celia Schultz on the basis of her work on animal and human sacrifice in late republican and early imperial Rome. In 'Sacrum reddere: Sacrifice, Consecration, and Dedication in Roman Religion', interest shifts to the terminology employed by Latin authors in referring to rituals that transfer property to the gods, in particular sacrificium and consecratio or dedicatio. Differences in the referents are not primarily different classes of objects, even if the first more frequently refers to animals and the latter to inanimate objects. Rather, it is the dialogical structure of the ritual sequences referred to and the possibility of the substitution of objects transferred. This leads to an interesting observation: By giving the quality of sacer, of the 'holy', a central place in our description of religions - for instance in the aftermath of Rudolf Otto's classic account ${ }^{5}$-, rituals that confer this very quality are seen as essential and take centre-stage in our descriptions of Roman religious practices. Roman discourse did not make this connection. Even if the terms are used in a comparable manner in antiquity and today, their interpretation with regard to the possibilities of application and variations could vary enormously and invalidate modern classifications. 
Jörg Rüpke critically reviews definitions of concepts such as 'votive' and 'altar' from an earlier period in his article, 'Gifts, Votives, and Sacred Things: Strategies, Not Entities'. Closer analysis of the complex development of the objects and rituals designated by such terms can show two very different developments of concepts. In one case, it is public legal concerns that lead to the development of a specific terminological solution that remains open for further generalisation. In the other case, different traditions of ritual action and etymologies are unified by drawing on previous Greek antiquarian discourse. It is in the history of the concept that terminological alternatives are identified. But it is also taken into account that some terms, such as (probably) votum and ludi, donum and sacer, reflect processes of conscious standardisation. In the course of time they served to justify certain practices and to protect the setting-up of the very objects of the archaeological record. The choice of words would not have been self-evident and accepted without such terminological labour. As such, they were taken up, or even enthusiastically embraced, by contemporaries or later users as they enabled them to determine vague ideas and unstable practices. Such ancient terminological strategies need to be made explicit and taken into account when they are used as modern terms of art or need to be replaced in order to allow for re-classification or more precise description and meaningful comparison. But above all, the article suggests focusing on identifying such strategies of religious action as are hidden behind, or simply lost through, the usage of terminological shorthand and basing comparison on these strategies rather than on a typology of rituals grounded in a language that is part of these strategies, rather than their precondition.

In 'The Matter of the Palmyrene "modius": Remarks on the History of Research into the Terminology of the Palmyrene Priestly Hat', Rubina Raja discusses and reviews the impact on scholarship of the application of ancient terminology to ancient objects, when we do not in fact know what these objects were called in antiquity. Raja takes as her point of departure the use of the word 'modius' for the Palmyrene priestly hat, which has been the accepted term in scholarship for a century but which is nowhere to be found in the sources. She examines and analyses what such well-meaning but inaccurate application of ancient terminology does to the way in which we understand and interpret objects. The conclusion is that the Palmyrene priestly hat does not have anything to do with either the representation of measuring units or with measuring units used as attributes of Greco-Roman fertility deities. It stood, rather, in a much more local tradition as a signifier of the elite status of Palmyrene priesthood. The term 'modius' should be abandoned, although the original term remains elusive to us. 
In the final article of the issue, Søren Lund Sørensen addresses primarily ancient terminological choices in his examination of the importance of the wording used in the oaths demanded of his subjects by Herod to affirm their loyalty to both the ruling house and the emperor. He analyses the wordings, as they are transmitted to us by Josephus in his Jewish Antiquities, and discusses what implications ancient terminology as recorded by a later writer has on the understanding of these oaths - both within their own time and the generations thereafter.

Through these contributions, we hope to spur interest in, and further engagement with, the field of terminology in an interdisciplinary setting and hope that fruitful discussions might arise from the approaches offered here.

\section{Bibliography}

Cancik, Hubert et al. 1988-2001. Handbuch religionswissenschaftlicher Grundbegriffe, 5 vols. Stuttgart: Kohlhammer.

Gallie, W. B. 1956. 'Art as an Essentially Contested Concept', Philosophical Quarterly 6 (23). 97-114.

Knöbl, Wolfgang 2007. Die Kontingenz der Moderne: Wege in Europa, Asien und Amerika. Theorie und Gesellschaft. Frankfurt a. M.: Campus.

Otto, Rudolf 1917. Das Heilige: Über das Irrationale in der Idee des Göttlichen und sein Verhältnis zum Rationalen. Breslau: Trewendt u. Granier.

Raja, Rubina; Rüpke, Jörg (eds.) 2015. Companion to the Archaeology of Religion. London: Wiley-Blackwell.

Taylor, Mark C. (ed.) 1998. Critical Terms for Religious Studies. Chicago: University of Chicago Press.

\section{Rubina Raja}

Centre for Urban Network Evolutions/Classical Art and Archaeology

Institute for Culture and Society

Aarhus University

Nobelparken 1461-326

8000 Aarhus C

Denmark

rubina.raja@cas.au.dk

\section{Jörg Rüpke}

Max-Weber-Kolleg für kultur- und sozialwissenschaftliche Studien

Universität Erfurt

Postfach 900221

99105 Erfurt

Germany

joerg.ruepke@uni-erfurt.de 



\section{Religion in the Roman Empire volume 4 (2018), No.2}

\section{Editors}

Jan Dochhorn (Durham), Maren Niehoff (Jerusalem), Rubina Raja (Aarhus), Christoph Riedweg (Zürich), Jörg Rüpke (Erfurt), Christopher Smith (St Andrews), Moulie Vidas (Princeton), Markus Vinzent (London) and Annette Weissenrieder (Halle)

Religion in the Roman Empire ( $R R E$ ) is bold in the sense that it intends to further and document new and integrative perspectives on religion in the Ancient World combining multidisciplinary methodologies.

Starting from the notion of 'lived religion' it will offer a space to take up recent, but still incipient research to modify and cross the disciplinary boundaries of 'History of Religion', 'Anthropology', 'Classics', 'Ancient History, 'Ancient Judaism, 'Early Christianity', 'New Testament', 'Patristic Studies', 'Coptic Studies', 'Gnostic and Manichaean Studies', 'Archaeology' and 'Oriental Languages'. It is the purpose of the journal to stimulate the development of an approach which can comprise the local and global trajectories of the multi-dimensional pluralistic religions of antiquity.

\section{Associate Editors}

Nicole Belayche (Paris), Kimberly Bowes (Rome), John Curran (Belfast), Richard L. Gordon (Erfurt), Gesine Manuwald (London), Volker Menze (Budapest), Blossom Stefaniw (Halle), Greg Woolf (London) 